\title{
GROWTH OF INVASIVE AQUATIC MACROPHYTES OVER TAPI RIVER
}

\author{
Shard Chander ${ }^{1 *}$, V. Pompapathi ${ }^{1}$, Ashwin Gujrati ${ }^{1}$, R. P. Singh ${ }^{1}$, Nehal Chaplot $^{2}$ and U. D. Patel ${ }^{2}$ \\ ${ }^{1}$ Space Applications Centre, ISRO, Ahmedabad 380 015, India- (schander*, pawoneco, ashwin8199, rpsingh)@ sac.isro.gov.in \\ ${ }^{2}$ Department of Civil Engineering, M.S. University of Baroda, Vadodara 500 037, India- npchaplot@ rediffmail.com, \\ patelupendra@gmail.com
}

Commission V. SS: Natural Resources Management

KEY WORDS: Aquatic marcophytes, water hyacinth, spectro-radiometer, water quality, remote sensing

\begin{abstract}
:
Aquatic macrophytes are important elements of freshwater ecosystems, fulfilling a pivotal role in the ecological functions of these environments and biogeochemical cycles. Although aquatic macrophytes are beneficial, some species can hinder human activity. They can clog reservoirs and reduce water availability for human needs. Surveys of macrophytes are hindered by logistic problems, and remote sensing represents a powerful alternative, allowing comprehensive assessment and monitoring. The objectives of this study was to map temporal changes in the macrophytes using time series multispectral dataset over Tapi River, Surat. The field trip was conducted over the Tapi River on $22^{\text {nd }}$ June 2018, where in-situ spectral response dataset were acquired using ASD Spectroradiometer. Water samples were also collected over three locations, one before entering the city (Kamrej), second at the Sarthana water treatment plant and third at the outer end (causeway). The nutrient concentration was less before entering the city (Ammonical Nitrogen $0.056 \mathrm{mg} / \mathrm{L}$ and phosphate $0.0145 \mathrm{mg} / \mathrm{l}$ ), while higher concentration (Ammonical Nitrogen $0.448 \mathrm{mg} / \mathrm{l}$ and phosphate $0.05 \mathrm{mg} / \mathrm{l}$ ) was observed within the city. Maps of aquatic macrophytes fractional cover were produced using Resourcesat2/2A (LISS-III) dataset covering a period of 2012-2018. Maximum extent was observed in February-March of every year. Although during monsoon, lot of agriculture run-off and nutrients will come into the river, but main flow of water will dilute its concentration. During summer, the same nutrient concentration will boost these macrophytes due to less availability of stream water. Within the area of $16 \mathrm{~km}^{2}$ between Kamrej and causeway, $3.35 \%$ was covered by macrophytes during March 2013. This area coverage increase to $36.41 \%$ in March 2018. Based on these maps, we discuss how remote sensing could support monitoring strategies and provide insight into spatial variability, and by identifying hotspot areas where invasive species could become a threat to ecosystem functioning.
\end{abstract}

\section{INTRODUCTION}

Water is the most important resource on earth providing numerous socio-economic and ecological benefits such as agricultural, industrial and domestic use. The world's freshwater resources are, however, on a steady decline, due to increased pressure resulting from poor domestic waste disposal, agricultural and industrial intensification, and consequently massive spread of aquatic macrophytes (Selman et al., 2008). Aquatic macrophytes are important components of inland water bodies (wetland, river) and play a crucial role in providing food and shelter for animals as well as regulating the water chemistry (McLachlan, 1974). They control erosion, improve water quality, and provides for an early warning signal for harmful algae blooms (Everitt and Elder, 2010). These plants may be free-floating or rooted in bottom sediment and submersed. However, on the other side, aquatic weed infestation is one of the major environmental challenges globally, threatening the integrity and functioning of most hydrological ecosystems (Cheruiyot et al., 2014). This invasion of foreign species leads to a number of ecological impacts, including reduced light and oxygen levels in the water column, which in turn reduces native macrophyte diversity. Water hyacinth and hydrilla are two exotic aquatic macrophytes that can causes significant ecological alterations in the invaded community by modifying the natural habitat (Coetzee et al., 2014).

* Corresponding author
Water hyacinth (figure 1 (a)) has been identified as one of the hundred most aggressive invasive species and recognized as one of the top 10 worst weeds in the world by the International Union for Conservation of Nature (IUCN) (Téllez et al., 2008). Although it is native to South America, it has become an environmental and social challenge throughout tropical and subtropical regions around the world. Téllez et al. 2008 have mapped worldwide distribution of water hyacinth. In its native range, water hyacinth plays a vital role for phytoplankton and zooplankton in freshwater ecosystems, by providing shelter and feeding grounds (Brendonck et al., 2003). The introduction of water hyacinth beyond its native range has altered the hydrology and chemistry of freshwater ecosystems. Its populations may double in size every 6-to18 days. Its optimum growth occurs between $28^{\circ} \mathrm{C}$ and $30^{\circ} \mathrm{C}$, and requires abundant nitrogen, phosphorus and potassium. However, these invasive species can survive in many different temperature, light, water, and soil conditions. This plant contains $95 \%$ of water. It has spongy fibrous tissue (as shown in figure 1 (b)) and a high energy and protein content that can be used for a variety of useful applications, i.e. fertilizers, animal fodder, paper industry, fuel pellets, making ropes, handicraft etc. It can also be used to aid the process of water purification. Water hyacinth is popular for aquarists as it reproduces extremely quickly and it produces large numbers of attractive purple flowers (Figure 1 (c)). Water hyacinth covers freshwater ecosystems in the form of dense, interlocking mats (Figure 1 (d)) due to its rapid reproductive rate and complex root structure (Mitchell, 1985). Therefore, it inhibits sunlight penetration into the lower parts of 
the waterbody and minimize the rate of photosynthesis for the submerged plants (Huang et al., 2007). These free-floating plant mats can be a serious threat to freshwater ecosystems biodiversity. Water hyacinth mats can be dangerous for recreational users of water by blocking/clogging of irrigation canals. They can clog reservoirs and reduce water availability for human needs. The presence of aquatic macrophytes in freshwater systems is, therefore, of great concern to environmentalists and hydrologists.
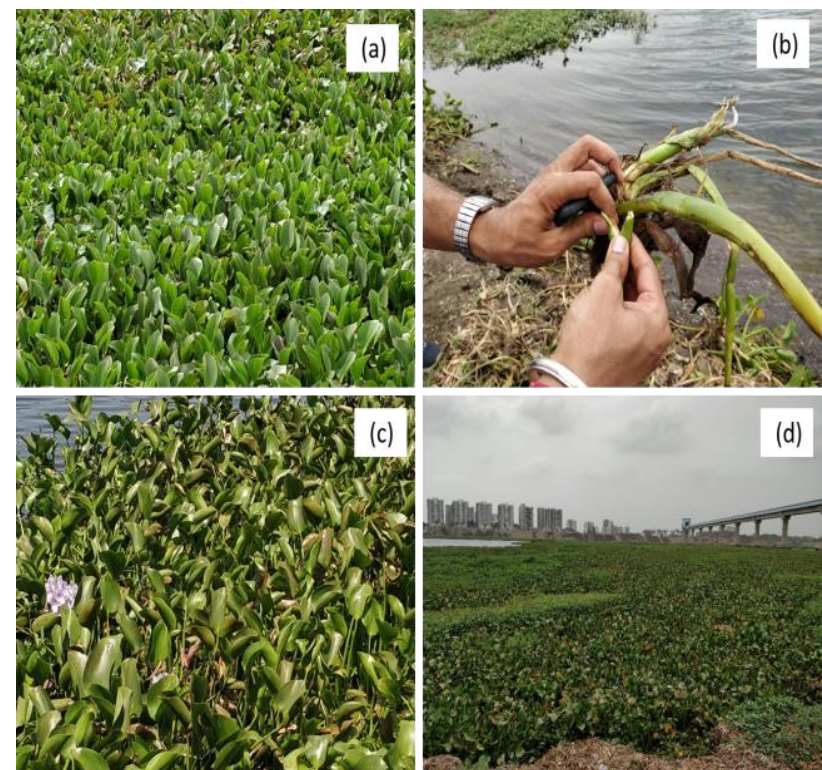

Figure 1. Field photographs of water hyacinth over the Tapi

River, close to Surat City in chronical order from left to right, (a) Water Hyacinth, (b) fibrous tissue, (c) Purple flower and (d) monospecific mats

The amount of water lost from a water body by a water hyacinth infestation can be up to three times larger than the natural evaporation rate of an uncovered water surface. These high levels are the result of high transpirations rates water lost through the leaves. This can have large impacts on water storages with infestations of water hyacinth and river systems that may already be low on water. Water quality is also affected in a number of ways following water hyacinth invasion. Dissolved oxygen levels are reduced beneath the floating mat by decreasing the natural transfer of oxygen from the air at the water surface. In addition, decomposing dead plant material can further reduce the amount of dissolved oxygen and increase the amount of sedimentation and silting in the water. These plants can form dense mats that reduce the water quality, change water flows and increase sediment. All of these factor lead to a decrease in water quality.

Uncontrolled city growth have led to heavy urban water pollution in the form of discharge of poorly treated municipal wastewater in the freshwater ecosystem. These freshwater pollution end up being deposited in surrounding waterbodies leads to water eutrophication and the proliferation of aquatic macrophytes. This eutrophication resulting from agricultural runoff and untreated sewerage further leads to increase higher hyacinth growth rates, and subsequently much higher impacts. The spread of aquatic macrophytes are linked to a number of land management practices (e.g. fertilizers or nutrients), as well as poor and uncontrolled discharge of sewage to river systems that create a conducive breeding ground for the growth of undesirable species (Giardino et al., 2015). In addition to nutrient concentrations, the spatial distribution and their spread also influenced by environmental factors, such as depth of the river, topography, type of soil substrates, water turbidity (Harvey et al., 1987).

Remote sensing has the ability to map these macrophytes in a large spatial/temporal prospective in a timely and cost-effective approach (Hestir et al., 2008). It can help in identifying potential vulnerable areas that experience aquatic macrophytes infestation. Most of the studies utilized remotely sensed data in monitoring lake conditions, but over rivers, only few studies have been done so far. Satellite remote sensing of small freshwater systems has been limited by the sensor characteristics, in terms of spectral, radiometric, temporal, and more importantly spatial resolution (Hestir et al., 2015). Satellite imagery has proved to be a reliable primary data source for mapping aquatic macrophytes (Oyama et al., 2015). Monitoring of aquatic macrophyte through remote sensing in freshwater ecosystem provides essential evidence to conserve both water quality and quantity. Detection and mapping the spatial distribution of these aquatic marcrophytes are important in understanding its spatial pattern and extent. This information is critical to aquatic scientists, environmentalists, and hydrologists, as well as catchment managers, especially in complex environments (Thamaga and Dube 2018).

Long-term mapping and continuous observation of the spatiotemporal distribution of aquatic macrophytes in inland hydrological systems are vital for a number of water resource management related reasons. Field surveys and water-related reports indicate that water hyacinth has invaded many water bodies in the tropical regions. Its spread is largely linked to eutrophication (poor land use management practices) and anthropogenic driven climatic change factors. It's well reported in lake and stagnant waters, but its distribution in streams and rivers is not yet fully understood. This gap in knowledge is mainly due to lack of in-situ dataset using traditional surveys and in-sufficient spatial resolution of the satellite dataset. In this study, we have used Resourcesat-2/2A (LISS-III) dataset for longer time duration for mapping the spatial distribution and configuration of invasive water hyacinth in one such river system, i.e. Tapi River. To further analyse the cause in the spread of macrophytes, laboratory analyses of the water samples were carried out to estimate the nutrient analysis and other water quality parameters.

\section{STUDY AREA AND MATERIAL USED}

\subsection{Study area}

The study was conducted at the Tapi River in Gujarat, on the west coast of India (Figure 2). The river traverses $724 \mathrm{~km}$ from its origin, to its final merger in the Gulf of Cambay in the Arabian Sea. The Tapi River is the main freshwater supply for the Surat city that has population close to 5 million. The river system has been affected by a widespread invasion by water hyacinth and has deteriorated by continuous accretion of fertilizers through run-off and disposal of raw sewage from the surrounding urban areas. Water hyacinth can create filth in the River water and damage machinery of intake wells used for fetching drinking water for the city. 


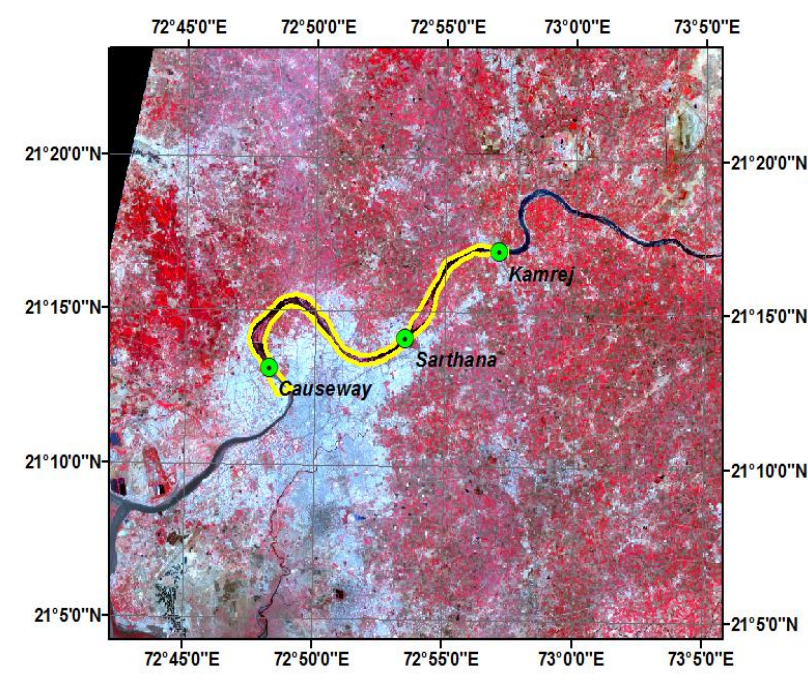

Figure 2. Study area Tapi River, green color marker shows the sampling locations and yellow color shape file highlights the extent of the river for the analysis

\subsection{Field survey/Data Collection}

A field trip was conducted over the Tapi River on $22^{\text {nd }}$ June 2018, where location of water macrophytes were mapped using using Global Position System (GPS). As shown in figure 2, the measurements were taken over three locations, one before entering the city (Kamrej), second at the Sarthana water treatment plant and third at the outer end (causeway). For further analysing the extent of the aquatic macrophytes, a precise river shape file was prepared between Kamrej and Causeway (shown in yellow color line in figure 2) that meanders within the Surat city.

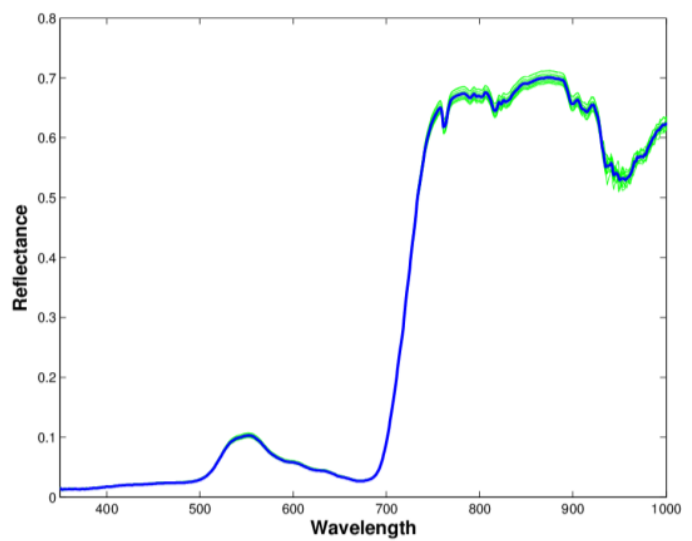

Figure 3. Reflectance spectra's of water hyacinth over the Tapi River, blue color represents the mean spectra

The spectral response dataset was acquired using portable highresolution Spectroradiometer (ASD FieldSpec Pro FR). Every time before measuring the water leaving radiance, incoming solar radiance was measured with the help of Spectralon white reference panel for accounting for changes in light conditions and instrument drift. The instrument averaged the readings to compensate for noise and ten readings were recorded at every location. Figure 3 shows one such reflectance spectra over the hyacinth. Field reflectance measurements showed that water hyacinth had higher near infrared (NIR) reflectance than associated plant species and water. Spectral signatures of hyacinth observed in the field had typical characteristics with low reflectance in visible region of the spectrum from 400 to $700 \mathrm{~nm}$, but high in the NIR region from 700 to $950 \mathrm{~nm}$. The internal spongy leaf structure reflects high in the NIR region from a wavelength of 700 to $1000 \mathrm{~nm}$ (Lillesand et al., 2008). The low reflectance observed for the visible region is due to the presence of high concentrations of chlorophyll-a, that is an indicator of healthy conditions of the aquatic vegetation.

\subsection{Laboratory analysis}

Water samples were also collected and analysed in the laboratory. Chlorophyll-a was estimated spectro-photometric using method $10200 \mathrm{H}$. Suspended particulate matter (SPM, 2540 D) was estimated using Gravimetric method. Other water quality parameters were also analysed using standard method, like $\mathrm{pH}$, Dissolved Oxygen (Iodometric method), Turbidity (Nephelometric Method), Conductivity, Ammonical Nitrogen (Titrimetric method), Phosphate-P (Stannous Chloride Method), and Nitrate (UV Spectrophotometric Screening Method) were analysed using procedures mentioned in parentheses as described in Standard Methods for the Examination of Water and Wastewater, $22^{\text {nd }}$ edition (Rice et al. 2012).

\section{RESULT AND DISCUSSION}

Cloudless satellite images of Resourcesat-2/2A (LISS-III, 24meter spatial resolution) covering the period of 2012-2018 over the Tapi River close to Surat city were processed to estimate the extent of the water hyacinth. The Normalized Difference Vegetation Index (NDVI) developed by Rouse et al. (1974) that is based on the contrast between the maximum absorption in the red region due to chlorophyll pigments and the maximum reflection in the infrared caused by leaf cellular structures is used as an indicator to map the surface floating water hyacinth. Total 65 scenes qualified the criteria of cloud cover less than 20 $\%$. NDVI threshold value greater than 0.4 was assigned as hyacinth cover based on the field measured spectra and GPS locations. For every year, the analysis has been done using post monsoon dataset and pre monsoon data of the next year, i.e. October 2012- April 2013 (2012-2013), similarly October 2017- April 2018 (2017-2018). The yearly statistics of the fractional coverage of hyacinth is shown in Table 1 . These pixels were then converted into fractional cover percentage by dividing with the total number of pixels within the river shape file.

\begin{tabular}{|l|l|l|l|l|l|l|}
\hline & $\begin{array}{l}\text { 2012- } \\
\text { 2013 }\end{array}$ & $\begin{array}{l}\text { 2013- } \\
\text { 2014 }\end{array}$ & $\begin{array}{l}\text { 2014- } \\
\text { 2015 }\end{array}$ & $\begin{array}{l}\text { 2015- } \\
\text { 2016 }\end{array}$ & $\begin{array}{l}\text { 2016- } \\
\text { 2017 }\end{array}$ & $\begin{array}{l}\text { 2017- } \\
\text { 2018 }\end{array}$ \\
\hline Min & 0.21 & 0.21 & 1.43 & 0.57 & 6.01 & 9.05 \\
\hline Max & 7.83 & 2.31 & 8.84 & 18.59 & 26.83 & 36.41 \\
\hline Mean & 2.85 & 0.89 & 3.67 & 9.37 & 20.05 & 26.70 \\
\hline
\end{tabular}

Table 1: Statistics of the aquatic macrophytes fractional area cover spread during 2012-2018 using LISS-III dataset

Maximum extent was observed in February-March of every year, while minimum was observed just after monsoon during October. Figure 4 shows the comparison of extent of hyacinth over the Tapi River during the period 2013-2018 for the maximum extent season (i.e. March of every year). The maximum spread was found close to the Sarthana treatment plan, in comparison to Kamrej. 


\begin{tabular}{|c|c|c|c|c|c|c|c|c|c|}
\hline Location & $\begin{array}{c}\text { Ammonical Nitrogen } \\
(\mathbf{m g} / \mathbf{l})\end{array}$ & $\begin{array}{c}\text { Phosphate } \\
(\mathbf{m g} / \mathbf{l})\end{array}$ & $\begin{array}{c}\text { Nitrate } \\
(\mathbf{m g} / \mathbf{l})\end{array}$ & $\begin{array}{c}\text { Chl- a } \\
(\boldsymbol{\mu g} / \mathbf{l})\end{array}$ & $\begin{array}{c}\text { CDOM } \\
\left(\mathbf{m}^{-1}\right)\end{array}$ & $\begin{array}{c}\text { D.O. } \\
(\mathbf{m g} / \mathbf{l})\end{array}$ & $\begin{array}{c}\text { COD } \\
(\mathbf{m g} / \mathbf{l})\end{array}$ & $\begin{array}{c}\text { SPM } \\
(\mathbf{m g} / \mathbf{l})\end{array}$ & $\begin{array}{c}\text { Turbidity } \\
(\mathbf{N T U})\end{array}$ \\
\hline Kamrej & 0.056 & 0.0145 & 0.3439 & 13.92 & 0.7599 & 6.5 & 44.8 & 3.75 & 6.3 \\
\hline Sarthana & 0.448 & 0.05 & 0.23095 & 29.40 & 0.783 & 6.25 & 22.4 & 5.75 & 6.3 \\
\hline Causeway & 0.336 & 0.04 & 0.1366 & 16.76 & 1.105 & 7.15 & 12.8 & 4 & 8 \\
\hline
\end{tabular}

Table 2: Laboratory results of water quality parameters collected during the field trip over Tapi River, Surat

Although during monsoon, lot of agriculture run-off and nutrients will come into the river, but main flow of water will dilute its concentration. During summer, the same nutrient concentration will boost these macrophytes due to less availability of stream water. Within the area of $16 \mathrm{~km}^{2}$ between Kamrej and causeway, $3.35 \%$ was covered by macrophytes during February-March 2013. This area coverage increase to $36.41 \%$ in March 2018.
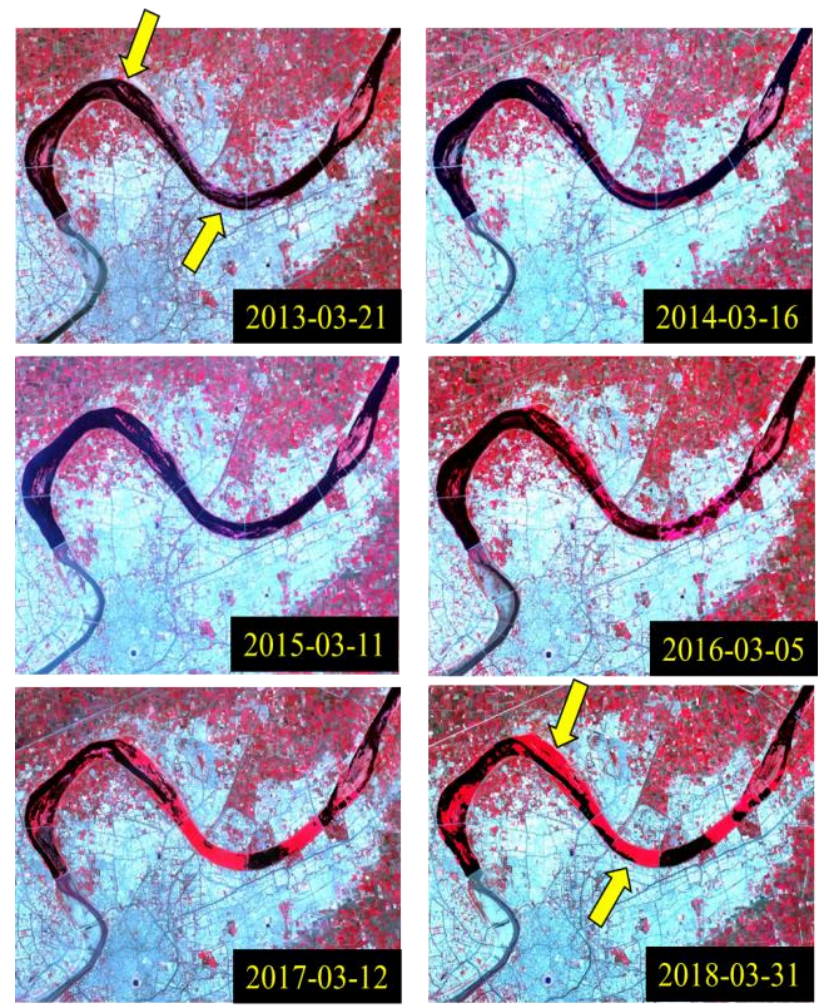

Figure 4. Multi-Year Observations of Macrophytes in Tapi River (Surat) from Resourcesat-2/2A (LISS-III) Series of Satellites

The increasing trend of Macrophytes in Tapi River (close to Surat) using multi-year satellite observations during the period 2012-2018 is shown in figure 5. The possible reason for the growth of hyacinth could be reduced water level in the river, the sewage in the upstream acts as nutrition for these aquatic plants and help them to grow faster. In Tapi River, there are at least 14 outlets in the upstream of the river starting from weir-cumcauseway to Kamrej throw all kinds of sewage into the riverbed. When water level is low, this untreated sewage acts as nutrition for weeds and help water hyacinth to grow faster. As it is clear from the results under high nutrient water levels, the growth of water hyacinth is dramatic, where it can quickly cover the entire water surface. Thus, waterbodies where water nutrient concentrations are often high due to agricultural runoff, deforestation and insufficient wastewater treatment are more prone to water hyacinth.

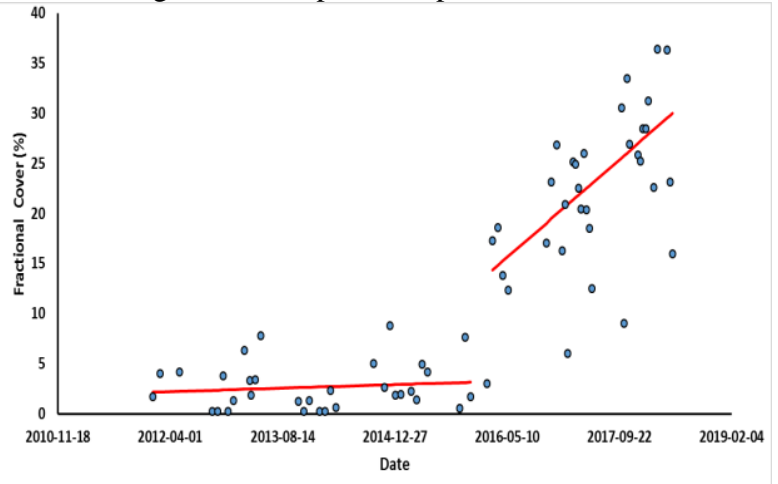

Figure 5. Increasing trend of Macrophytes in Tapi River (close to Surat) using multi-year satellite observations

Nutrient levels and water-level fluctuations are two important factors that affect the development and growth of macrophytes. For most of the time of the year, Tapi River has been converted into impoundments that provide an ideal habitat for these floating species. As these aquatic macrophytes can affect the water quality as well, we have also analysed the physical and biological water quality parameter as shown in Table 2 . The water was found to be sufficiently productive with chlorophyll-a cocentarion within a range 13.92-29.40 $\mu \mathrm{g} / \mathrm{l}$, with maximum value at the centre of the city (Sarthana). Color dissolved organic matter (CDOM) was found to be high within range of $0.75-1.1 \mathrm{~m}^{-1}$, with maximum value at the causeway location. Suspended particulate matter (SPM) was varying between 3.75$5.75 \mathrm{mg} / \mathrm{l}$, with highest concentration close to water treatment plant. The dissolve oxygen (DO) was found to be low overall within the rage of $6.25-7.15 \mathrm{mg} / \mathrm{l}$ with minimum value at Sarthana water treatment plant. The nutrient concentration was less before entering the city (Ammonical Nitrogen $0.056 \mathrm{mg} / \mathrm{l}$ and phosphate $0.0145 \mathrm{mg} / \mathrm{l})$, while higher concentration (Ammonical Nitrogen $0.448 \mathrm{mg} / \mathrm{l}$ and phosphate $0.05 \mathrm{mg} / \mathrm{l}$ ) was observed within the city.

Once established these aquatic macrophytes are difficult to control and are nearly impossible to eradicate. The main mechanisms for preventing the spread of water hyacinth are biological, chemical and physical control (Williams et al., 2005). The main concern when using Chemical control is the environmental and health related effects, especially where people collect water for drinking and washing. Biological control is the safest method, but it is too slow to implement practically. Physical control is the only method that is used widely but is costly and cannot deal with very large infestations.

\section{CONCLUSIONS}

Monitoring the health of the aquatic ecosystem is important to insure the availability of safe drinking water. Temporal analysis of satellite images have shown that water hyacinth has covered a large portion of Tapi River close to Surat city. Its spread has increased significantly in the last three year (2016-2018) at an alarming rate. Upto 2015, water macrophytes were found to be less than 10 percentage of the total area coverage, but since then 
a sudden rise in the macrophytes was observed that rises up to $36 \%$ in March 2018. The spread of the this fast-growing water hyacinth weed in Tapi River and other open water sources is threatening the city's main water supply. This information could support monitoring strategies by identifying hotspot areas where invasive species could become a threat to ecosystem functioning. Although municipal corporations are trying to evacuate these invasive macrophytes, but removal of water hyacinth is just a temporary solution. Until and unless the untreated sewage outlets are not stopped merging in the River this problem will never end. Thus, actions that are more stringent are required from concern authorities to control these aquatic macrophytes growth.

\section{ACKNOWLEDGEMENTS}

We express our sincere gratitude to Shri D. K. Das, Director and Dr Raj Kumar, Deputy Director EPSA for providing overall support. The guidance and encouragement received from Dr. A. S. Rajawat, Group Director, GHCAG are acknowledged with thanks. The authors would like to thank the authorities of ISRO for providing financial grant for this research work (Project Line Item Code: 0303611RM201). Thanks are also due to Surat Municipal Corporation for helping in conducting the field survey overt the Tapi River.

\section{REFERENCES}

Brendonck, L., Maes, J., Rommens, W., Dekeza, N., Nhiwatiwa, T., Barson, M., Callebaut, V., Phiri, C., Moreau, K., Gratwicke, B., Stevens, M., Alyn, N., Holsters, E., Ollevier, F., Marshall, B., 2003. The impact of water hyacinth (Eichhornia crassipes) in a eutrophic subtropical impoundment (Lake Chivero, Zimbabwe). II. Species diversity. Arch. Hydrobiol, 158, 3, pp. 389-405.

Cheruiyot, E. K., Mito, C., Menenti, M., Gorte, B., Koenders, R., Akdim, N., 2014. Evaluating MERIS-based aquatic vegetation mapping in Lake Victoria. Remote Sensing, 6(8), pp. $7762-7782$.

Coetzee, J. A., Jones, R. W., Hill, M. P., 2014. Water hyacinth, Eichhornia crassipes (Pontederiaceae), reduces benthic macroinvertebrate diversity in a protected subtropical lake in South Africa. Biodivers Conserv, 23, pp. 1319-1330.

Everitt J. H., Elder S. H., 2010. Evaluating airborne multispectral digital video to differentiate Giant Salvinia from other features in Northeast Texas. Remote Sensing, Vol 2, Issue 10, pp. 2413-2423.

Giardino, C., Bresciani M., Valentini E., Gasperini L., Bolpagni R., and Brando V. E., 2015. Airborne Hyperspectral Data to Assess Suspended Particulate Matter and Aquatic Vegetation in Shallow and Turbid Lake. Remote Sensing of Environment, Vol. 157, pp. 48-57, doi:10.1016/j.rse.2014.04.034.

Harvey, R. M., Pickett J. R. and Bates R. D., 1987. Environmental Factors Controlling the Growth and Distribution of Submersed Aquatic Macrophytes in Two South Carolina Reservoirs. Lake and Reservoir Management, Vol. 3, pp. 243255, doi:10.1080/07438148709354780.

Hestir, E. L., Brando, V. E., Bresciani M., Giardino C., Matta E., and Villa P., 2015. Measuring Freshwater Aquatic Ecosystems: The Need for a Hyperspectral Global Mapping
Satellite Mission. Remote Sensing of Environment, 167: 181195, doi:10.1016/j.rse.2015.05.023.

Hestir, E. L., Khanna, S., Andrew, M. E., Santos, M. J., Viers, J. H., Greenberg, J. A., 2008. Identification of invasive vegetation using hyperspectral remote sensing in the California Delta ecosystem. Remote Sensing of Environment, 112, 40344047.

Huang, X. Y., Lan, J. L., Su, M. X., Shi, H., Lin, K. M., Zhu, Y. Q., 2007. Polymorphism of biological characteristics of Eichhornia crassipes. Chin. Agric. Sci. Bull., 23(8), 98-101.

Lillesand T. M., Kiefer R. W., Chipman J. W. 2008. Remote Sensing and Image Interpretation, $6^{\text {th }}$ edition. John Wiley and Sons, New York, NY, USA.

McLachlan, A. J., 1974. Recovery of mud substrate and its associated fauna following a dry phase in a tropical lake. Limnology and Oceanography banner, Vol 19, Issue 1, pp 7483.

Mitchell D. S., 1985. Surface-floating aquatic macrophytes. In: The Ecology and Management of African Wetland Vegetation (Eds P. Denny), pp. 109-124.

Oyama, Y., Mantsushita, B., Fukushima, T., 2015. Distinguishing surface cyanobacterial blooms and aquatic macrophytes using Landsat/TM and ETM+ shortwave infrared bands. Remote Sensing of Environment, Vol. 157, pp. 35-47.

Rice E. W., Baird R. B., Eaton A. D., Clesceri L. S., 2012. Standard methods for the examination of water and wastewater $22^{\text {nd }}$ edition, American Public Health Association, American Water Works Association, Water Environment Federation, ISBN:9780875530130.

Rouse, J. W., Haas, R. H., Schell, J. A., Deering, D. W., Harlan, J. C. 1974. Monitoring the Vernal Advancements and Retrogradation (green wave effect) of Natural Vegetation. In: NASA/GSFC, Final Report, Greenbelt, USA, 1-137.

Selman, M., Greenhalgh, S., Díaz, R., Sugg, Z., 2008. Eutrophication and Hypoxia in Coastal Areas: a Global Assessment of the State of Knowledge. World Resources Institute (WRI) Policy Note, Washington D.C, No 1, pp. 6.

Téllez, T., Lopez, E., Granado, G., Pérez, E., Lopez, R., Guzmon, J., 2008. The water hyacinth, Eichhornia crassipes: an invasive plant in the Guadiana River Basin (Spain). Aquatic Invasions Volume 3, Issue 1, 42-53.

Thamaga, K. H. and Dube, T., 2018. Testing two methods for mapping water hyacinth (Eichhornia crassipes) in the Greater Letaba river system, South Africa: discrimination and mapping potential of the polar-orbiting Sentinel-2 MSI and Landsat 8 OLI sensors. International Journal of Remote Sensing, doi: 10.1080/01431161.2018.1479796.

Williams, A. E., Duthie, H. C., Hecky, R. E., 2005. Water hyacinth in Lake Victoria: why did it vanish so quickly and will it return?. Aquat. Bot., 81(4), 300-314. 